\title{
The Effect of GnRH on Reproductive Performance and Progesterone Hormone Levels in Buffalo in West Sumatera
}

Tinda Afriani ${ }^{1 *}$, Ferdinal Rahim ${ }^{1}$, Mangku Mundana ${ }^{1}$, Arif Rahmat ${ }^{1}$, Jaswandi ${ }^{2}$, Anna Farhana ${ }^{2}$

${ }^{1}$ Department of Livestock Production, Faculty of Animal Science, Andalas University

${ }^{2}$ Laboratory of Animal Biotechnology, Department of Animal Technology and Reproduction, Faculty of Animal Science, Andalas University

\section{ARTIKEL INFO}

Sejarah artikel

Diterima 30/09/2020

Diterima dalam bentuk revisi 07/11/2020

Diterima dan disetujui 10/11/2020

Tersedia online 23/12/2020

Kata kunci

Dadih

Hormon GnRH

Kerbau rawa

Tingkat progesterone

Respon estrus

\section{ABSTRAK}

Penelitian ini bertujuan untuk mengetahui dosis GnRH terbaik, onset, lama estrus, dan kadar progesteron pada Kerbau Rawa penghasil dadih di Indonesia. Materi yang digunakan yaitu 16 ekor induk Kerbau Rawa dengan bobot badan rata-rata $500 \mathrm{~kg}$ dan usia antara 3-5 tahun. Metode penelitian menggunakan Analisis of Varian (Anova) dari RAL (Rancangan Acak Lengkap) dengan berbagai tingkatan dosis FSH yang digunakan pada Kerbau Rawa. Kerbau Rawa diatur berahinya dengan melakukan sinkronisasi dengan injeksi hormon GnRH sebanyak $5 \mathrm{ml}$ pada hari pertama dan ke-11, pada hari ke-10 sampai ke-12 semua kerbau donor diinjeksi dengan GnRH. Injeksi GnRH menggunakan 4 dosis sebagai perlakuan yaitu 200, 225, 250, and $275 \mathrm{ml} / \mathrm{kerbau}$, setiap perlakuan terdiri dari 5 ulangan. Kecepatan estrus, lama estrus dan kadar progesteron merupakan variabel yang diukur. Hasil penelitian menunjukkan bahwa dosis GnRH secara nyata $(\mathrm{P}<0,05)$ meningkatkan kecepatan estrus dan lama estrus. Kadar progesteron meningkat secara signifikan mulai dari sebelum perlakuan sampai setelah perlakuan dengan GnRH. Disimpulkan bahwa dosis GnRH terbaik untuk sinkronisasi estrus pada kerbau rawa penghasil dadih adalah $225 \mathrm{ml}$ dengan kecepatan estrus 18,2 jam dan panjang estrus 18 jam. 


\section{ABSTRACT}

This study aims to determine the best dose of GnRH, onset, duration of estrous and progesterone level on the swamp buffalo production of dadih in Indonesia. The materials used were 16 Swamp Buffalo with an average body weight of $500 \mathrm{~kg}$ and aged between 35 years The research method using analysis of variants (ANOVA) of the CRD (completely randomized design) with different levels of FSH dose used. Swamp Buffalo is synchronized with the injection of $5 \mathrm{ml}$ of GnRH hormone $n$ on the first and 11th day, on the 10th to 12th day all donor buffaloes are injected with GnRH. Four different doses of

\section{INTRODUCTION}

Swamp buffalo are animals commonly raised for meat throughout SEA Asia. The implementation of reproductive technologies, especially artificial insemination (AI) of buffalo in Indonesia still has many obstacles, characterized by high service per conception (S/C) ratio and repeated breeding (Ihsan, 2011; Ismaya, 2014). AI which is seldom performed in buffalo, because of the weakness of estrus symptoms and the variability of estrus length is very difficult (Yendraliza et al. 2011). Even though these animals are chiefly raised for their meat rather than as dairy animals, farmers in West Sumatra make a yoghurt-like fermented food from buffalo milk known as dadih which has $43 \%$ lower cholesterol and $65 \%$ higher calcium than that made from cows. It contains antioxidants, that have benefits for human health.

The market for dadih is at present limited to West Sumatera but has the potential to be widened especially with the current interest in probiotic foods. Dadih was traditionally only fermented in bamboo, however, over the food
GnRH (200, 225, 250, and $275 \mathrm{ml} / \mathrm{buffalo})$ and each treatment was replicated five times. The speed of estrus and estrus length were the measured variables. The results showed that the doses of GnRH significantly $(P<0.05)$ increase of estrus speed and estrus length. Progesterone levels have increased significantly starting from before treatment until after treatment with GnRH. It is concluded that the best GnRH doses for estrus synchronization in the swamp buffalo producing of dadih was $2.25 \mathrm{ml} / \mathrm{buffalo}$ with estrus speed $18.2 \mathrm{~h}$ and estrus length $18 \mathrm{~h}$.

processing technology has made its manufacture more efficient.

This decline of buffalo population is due to uncontrolled marital management, difficulty in providing superior males, and maintenance goals are still considered as side jobs. When buffalo are regularly milked estrus is delayed further. Environmental management limitations are a lack of knowledge and application of reproduction technology. In many parts of Asia, farmers know very little about how to detect estrus (Jessie et al. 2016).

Problems with livestock systems and farmers' skills and knowledge limitations can be improved through training, counseling and mentoring (Chaikhun et al. 2010). Buffaloes often experience silent heat meaning that they do not clearly show signs of estrus so that the farmer does not know the right time to mate the buffalo either naturally or with $\mathrm{AI}$ at the right time. The condition of silent heat in buffalo makes it difficult for farmers to develop buffalo cattle. This condition was natural and cannot be genetically removed. The condition of silent heat results in the difficulty of farmers in detecting estrus in buffaloes, so that the success 
of AI implementation is still relatively low and birth intervals (Redhead et al. 2018).

Reproductive technology that can be applied is synchronizing estrus by utilizing exogenous hormones including GnRH (Nalley et al. 2011; Jordiansyah et al. 2013). GnRH is a natural hormone produced by the hypothalamus in the brain that can produce another hormone called Luteinizing Hormone (LH) in collaboration with Follicle Stimulating Hormone (FSH) in follicular development and the onset of signs of estrus. (Afriani et al. 2014) GnRH injection of 48 hours caused more ovulation to occur in response to the release of FSH and LH by hypophysis due to GnRH stimulation. GnRH injection in each estrus cycle will ovulate the dominant follicles that exist and the emergence of new follicular waves 2 or 3 days later (Arum et al. 2013; Rabidas et al. 2017).

The application of estrus synchronization technology with the use of the GnRH hormone could be expected to improve the reproductive performance of milk-producing buffalo. Along with improvements to the housing system and feed provision and increasing dadih shelf-life this will enable the dadih industry to expand and flourish. Based on that described above, study is conducted to determine the best dose of GnRH in the process of estrus synchronization on buffalo swamp.

\section{METHODS}

\section{Buffalo}

As many as 16 Swamp Buffalo producing of dadih were used in this study with an average body weight of $500 \mathrm{~kg}$ and aged between 3-5 years.
The reason for choosing this age range was that the average age at first mating for buffalo is been found to be $2.8 \pm 0.3$ years (Afriani et al. 2018). Buffalo was chosen with purposeful sampling from three breeders using intensive farming methods.

\section{Research materials and tools}

The material used is GnRH, PGF2 $\alpha$, FSH, physiological $\mathrm{NaCl}, \mathrm{NaOH}$, Ethanol, Methanol. The tool used is petridish 35 and 60 $\mathrm{mm}$, pasteur pipette, disposable syringe, glass cover, gas pack. As well as the main tools used include incubators, electric scales, ovens, eppendorf pipettes, refrigerators, centrifuge.

\section{Experimental design}

A completely randomized study design with 4 treatments and 5 replications. each replication consisted of 5 (five) buffalo as experimental units, namely treatment A. (200 $\mathrm{ml} /$ buffalo), B. (225 $\mathrm{ml} /$ buffalo), C. (250 $\mathrm{ml} /$ buffalo), and D. (275 $\mathrm{ml} /$ buffalo). Synchronization was achieved by injecting GnRH on day 0, day 7 then two days later GnRH, after which estrus was detected. The speed of estrus, estrus length, and progesterone levels were the measured variables. For the analysis of buffalo-producing dadih, blood samples were used by using the ELISA method to observe progesterone levels.

\section{Statistical analysis}

All data were analyzed by analysis of variance (ANOVA) using a general linear model procedure on SPSS software version 16.0. Duncan's multiple range test was used for the determination of differences between treatment means. 
RESULTS AND DISCUSSION

\section{Estrus Speed and Estrus Length}

Analysis of variance indicated that four

doses of $\mathrm{GnRH}$ significantly $\quad(\mathrm{P}<0.05)$

influential on the speed estrus in the swamp buffalo producing of dadih. Table 1 shows that the estrus speed of the swamp buffalo producing of dadih on treatment $225 \mathrm{ml} /$ buffalo produced the fastest estrus; 18.2 hours after the second GnRH injection.

Table 1. Average Estrus Speed (Hours) and Length of Estrus (Hours) in The Swamp Buffalo Producing of Dadih After Injection of GnRH With Different Doses

\begin{tabular}{cll}
\hline $\begin{array}{l}\text { The Dosages of GnRH } \\
\text { (ml/buffalo) }\end{array}$ & Estrus Speed (h) & Estrus Length (h) \\
\hline A. 200 & $29.4^{\mathrm{ab}}$ & $16^{\mathrm{a}}$ \\
B. 225 & $18.2^{\mathrm{c}}$ & $18^{\mathrm{a}}$ \\
C. 250 & $32.4^{\mathrm{a}}$ & $22^{\mathrm{b}}$ \\
D. 275 & $28.6^{\mathrm{b}}$ & $18.6^{\mathrm{a}}$ \\
\hline
\end{tabular}

Note: Data presented as the mean of 5 replicates, a-c Values in the same column with different superscript letters are significantly different $(\mathrm{P}<0.05)$

Based on Table 1. This was statistically faster than any other dosage trial. The results showed that GnRH injection can affect estrus speed in the swamp buffalo production of dadih. GnRH can stimulate FSH, which function in stimulating follicle growth in the ovary. The appearance of estrus is due to the influence of the increase in the estrogen hormone in the body produced by the ovum. GnRH injection in treatment B (225 ml/buffalo) shows that the speed of estrus emergence most quickly when compared to treatments A, C, and D. This is caused by the injection of GnRH at a dose of $225 \mathrm{ml} /$ buffalo there is a lot of follicle formation. This is similar to that obtained by (Yendraliza et al. 2017) that the magnitude of the percentage change in buffalo behavior given GnRH-PGF2 $\alpha$ from buffaloes which do not get additional synchronous hormones, probably caused by the number of follicles formed due to the addition of GnRH. The addition of the GnRH will stimulate follicle growth (Ibrahim 2008). GnRH gave on the first day, PGF2 $\alpha$ on day 7th and GnRH on the 9th day showed a significant influence between estrus response and pregnancy in Mediterranean swamp buffalo (Neglia et al. 2016).

The speed of estrus (onset of estrus) is the time when animals show signs of estrus for the first time. The ultimate goal of estrus seizure in the swamp buffalo production of dadih is to increase reproduction with the presence of clear estrus signs so that it can improve time efficiency for AI which will ultimately increase the production of dadih. The average speed of estrus the swamp buffalo producing of dadih in treatment B (225 ml/buffalo) is $18.2 \mathrm{~h}$. The results of this study similar to that obtained by (Yendraliza et al. 2017) synchronization protocol on female buffaloes in Kabupaten Kampar using combinations of GnRH and PGF $2 \alpha$ in postpartum period make higher estrus intensity, faster estrus and longer estrus duration, the estrus speed (30.80 hours to 2.5 hours), and estrus length (18.6 hours to 6.5 hours).

Analysis of variance indicated that four doses of $\mathrm{GnRH}$ significantly $\quad(\mathrm{P}<0.05)$ 
influential on the estrus length in the swamp buffalo producing of dadih. Table 1 showed that estrus length of the swamp buffalo producing of dadih on treatment $200 \mathrm{ml} /$ buffalo produced the fastest estrus; $16 \mathrm{~h}$ after the second $\mathrm{GnRH}$ injection, however, it was not significantly different $(\mathrm{P}>0.05)$ from treatment B (225 $\mathrm{ml} / \mathrm{buffalo}$ ) with estrus length is $18 \mathrm{~h}$. The length of estrus is the time interval between the onset of estrus and the completion of the estrus period. The estrus length is also influenced by age, body condition, and the types of hormones used for synchronization or estrus induction (Irmaylin et al. 2012).

The results show that injection of GnRH can affect the estrus duration in the swamp buffalo production of dadih. This is caused by differences in the dose of GnRH injection which can affect the duration estrus of buffalo. The difference in the duration of estrus in female swamp buffalo is caused by the difference in the number of doses of GnRH given which will affect the length of work of PGF2 $\alpha$ (Yendraliza et al. 2012). Estrus length is the time shown by buffalo with the first range showing signs of estrus and loss of estrus signs in buffalo. Increasing the dose of GnRH synchronized with PGF2 $\alpha$ produced different estrus length (Yendraliza et al. 2012).

Genetic improvement can be obtained by improving feed management and reproduction in buffalo, one of one effort that can be done is injecting GnRH, day 1st, followed by PGF2 $\alpha$, 7th day; then GnRH 9th day; and IB, 10th day. Improve genetic quality and increase livestock populations, requires serious handling and attention in buffalo, because of the phenomenon of difficulty detecting heat related to the phenomenon of silent heat. Reproduction improvement is aimed at improving reproductive efficiency through regulating the marriage system and accurate detection of estrus or estrus striking which ends with marriage which results in a maximum number of pregnancies (Forde et al. 2011; Ismaya, 2014).

In order improve reproductive efficiency, various synchronization protocols for buffalo have been made to regulate the estrous cycle and ovulation. It has been reported that following gonadotropin-releasing hormone $(\mathrm{GnRH})$ associated with PGF 2 administration and timed artificial insemination, the percentage of ovulating buffaloes were $60-90 \%$ (Chaikhun et al 2010) with conception rates recorded as $32.7 \%-60 \%$ during the breeding season (Konrad et al 2013). Buffaloes were treated with progesterone (P4)-releasing intravaginal device (PRID) along with pregnant mare serum gonadotropin (PMSG) and PGF 2, the ovulation rate during the low breeding season and breeding season was $58.3 \%$ and 91.7\%, respectively (Barile et al. 2015) and pregnancy rate was between $28 \%$ and $52.7 \%$ during the non-breeding season (Neglia et al. 2016; Carvalho et al. 2013). (Neglia et al 2016) observed a pregnancy rate of $45 \%$ in buffalo cows synchronized with PGF2 $\alpha$ alone and $48.8 \%$ when PGF2 $\alpha$ was combined with GnRH injection at the time of AI. Similarly, 33.3, 43.7, 36.0 , and a 15.0 vs. $51.4 \%$ pregnancy rate was recorded in Murrah buffalo, Italian buffalo, Italian cyclic buffalo and Swamp buffalo heifers vs. cows after using the ovsynch 
protocol and timed insemination, respectively. In the current study, the circulating concentrations of progesterone precisely indicated the presence or absence of a CL and reflected its size and activity (Chaikhum et al. 2010; Neglia et al. 2016) The average ostrus length of the swamp buffalo producing of dadih in treatment B (225 ml/buffalo) is $18 \mathrm{~h}$. According to Barile (2015) who reported that the average onset of estrous was $54.6 \mathrm{~h}$ in buffaloes.

\section{Progesterone levels}

The levels of the hormone progesterone in each treatment table below.

Table 2. Progesterone levels at a several doses of GnRH

\begin{tabular}{cccc}
\hline \multirow{2}{*}{ Doses GnRH $(\mathrm{ml})$} & \multicolumn{3}{c}{ Progesteron Levels $(\mathrm{ng} / \mathrm{ml})$} \\
\cline { 2 - 4 } & Days - 0 $(\mathrm{A})$ & Days - 3 $(\mathrm{B})$ & Days - 12 $(\mathrm{C})$ \\
\hline 220 & $4,012^{\mathrm{A}}$ & $6,096^{\mathrm{B}}$ & $8,667^{\mathrm{C}}$ \\
225 & $2,989^{\mathrm{A}}$ & $5,880^{\mathrm{B}}$ & $9,587^{\mathrm{C}}$ \\
250 & 3,386 & 6,298 & 8,413 \\
275 & $2,901^{\mathrm{A}}$ & $5,901^{\mathrm{B}}$ & $7,988^{\mathrm{C}}$ \\
\hline
\end{tabular}

Note: $A B C$ superscript value that showed very significant difference $(\mathrm{p}<0.01)$

The results showed that the administration of GnRH at doses of $200 \mathrm{ml}, 225$ $\mathrm{ml}$, and $275 \mathrm{ml}$ showed significant $(\mathrm{p}<0.01)$ results on progesterone levels in buffaloes. However, administration of a $250 \mathrm{ml}$ dose level gives a significantly different increase to buffalo progesterone levels on the 12th day was the high level of progesterone in the $225 \mathrm{ml}$ treatment. The highest level of progesterone in the luteal phase occurred on day 21 , amounting to $5.21 \mathrm{ng} / \mathrm{ml}$ and the lowest level at the beginning of the phase was $0.40 \mathrm{ng} / \mathrm{ml}$. In the follicle phase, progesterone levels are generally low in sores ranging from $0.07 \mathrm{ng} / \mathrm{ml}$ to 0.55 $\mathrm{ng} / \mathrm{ml}$ (Bearden et al. 2004).

\section{CONCLUSION}

It is concluded that the best GnRH doses for estrus synchronization in the swamp buffalo producing of dadih was $225 \mathrm{ml} / \mathrm{buffalo}$ with estrus speed $18.2 \mathrm{~h}$ and estrus length $18 \mathrm{~h}$. Progesterone levels have increased significantly starting from before treatment until after treatment with GnRH.

\section{ACKNOWLEDGEMENT}

Gratitude is expressed to the rector of Andalas University Padang, Indonesia and LPPM Andalas University who funded this research with grant number 047/SP2H/PPM/DRPM/2020.

\section{REFERENCES}

Afriani T, Jaswandi., Defrinaldi., \& Y E Satria. (2014). Pengaruh Waktu Pemberian Gonadotropin Releasing Hormone (GnRH) terhadap Jumlah Korpus Luteum dan Kecepatan Timbulnya Berahi pada Sapi Pesisir. Jurnal Peternakan Indonesia, 16 (3).

Afriani, T., James, H., Purwanti, E., Ferdinal, R., Arif, R., Jaswandi., \& Mangku, M. (2018). Reproductive Technology in Buffalo. Andalas University Press, Padang.

Arum, W. P., Tongku, N. S., \& Juli, M. (2013). The Effect of Bovine Pituitary Extract on Superovulatory Response of Aceh Cattle. J. Medika Veterinaria, 7 (2), 71-74. 
Barile V L., Terzano G M., Pacelli C., Todini L., Malfatti A., \& Barbato O. (2015). LH peak and ovulation after two different estrus synchronization treatments in buffalo cows in the day light - leng then in period. Theriogenology, 84(2), 286-293.

Bearden, H.J., J.W. Fuquy., \& S.T. Willard. (2004). Applied animal reproduction. 6th ed. New Jersey, Prentice Hall, Upper Sadlle River. pp. 44-207.

Carvalho N A., Soares J G., Porto Filho R M., Gimenes L U., Souza D C., Nichi M., Sales J. S., \& Baruselli P S. (2013). Equine chorionic gonadotropin improves the efficacy of a timed artificial insemination protocol in buffalo during the nonbreeding season. Theriogenology, 79(1), 423-428.

Chaikhun T., Tharasanit T., Rattanatep J., De Rensis F., \& Techakumphu M. (2010). Fertility of Swamp Buffalo Following the Synchronization of Ovulation by The Sequential Administration of GnRH and $\mathrm{PGF}_{2}$ alpha Combined with Fixed-Timed Artificial Insemination. Theriogenology, 74(2): 1371-1376.

Forde, N., M. E. Beltman, P. Lonergan, M. Diskin., J. F. Roche., \& M. A. Crowe. (2011). Oestrous cycles in Bos taurus cattle. J. Anim. Reprod. Sci. 124(1): 163169.

Ihsan, M.N. (2011). Ilmu Reproduksi Ternak Dasar. Universitas Brawaijaya Press (UB Press). Hal. 139-171.

Irmaylin S M., Hartono M., \& Santosa P E. (2012). Response to the Speed of Estrus and Estrus Length at Parities Various of Ongole Breeds After Twice Injecting Prostaglandin F2 $\alpha$ (PGF2 $\alpha$ ). Journal Kedokteran Hewan, 2(1): 41-49.

Ismaya. (2014). Artificial Insemination Biotechno-

logy in Cows and Buffalo. Gadjah Mada University Press. Yogyakarta. Thing. p. 60-85.

Jessie, W.; Maddison., Jessica, P., Rickard, E., Mooney, C., Naomi., Bernecic, C., Soleilhavoup, G., Tsikis, X., Druart, T., Leahy, P., \& Simon G. (2016). Oestrus synchronisation and superovulation after the production and biochemical constituents of ovine cervicovaginal mucus. J. Anim. Reprod. Sci, 172(1), 114 122.

Jordiansyah, S. M., Imron., \& Sumantri, C. (2013). The level of superovulation and embryo production in vivo with CIDR (Controlled Internal Drug Releasing) synchronization in simmental donor cows. J. of Anim. Husbandry Production and Technology, 1 (3), 184-190.

Konrad J L., Olazarri M J., Acuna M B., Patino E M., \& Crudeli D A. (2013). Effect of Use Pre-Synch + Ovsynch Protocols on the Pregnancy of the Buffalo Rodeo of the Argentinean NEA. Buffalo Bulletin, 32(1): 177-180.

Nalley, W.M.M., R. Handarini., R.I. Arifiantini, T.L. Yusuf, B. Purwantara., \& G. Semiadi. (2011). Estrus synchronization and artificial insemination In timor deer. $J$. Veteriner. 12(2): 269-274.

Neglia G., Gasparrini B., Salzano A., Vecchio D., De Carlo E., Cimmino R., Balestrieri A., D'Occhio M. J., \& Campanile G. (2016). Relationship between the ovarian follicular response at the start of an Ovsynch-TAI program and pregnancy outcome in the Mediterranean river buffalo. Theriogenology; 86(9): 23-33.

Rabidas, Susanto and Royhan G. 2017. Synchronization of Estrus Using Ovsynch Protocol and Fixed Timed Artificial Insemination (FTAI) in Indigenous Dairy Buffaloes: An Effective Buffalo Breeding Program in Bangladesh. Asian Journal Of Biology, 2 (1) : 1-8.

Redhead, A.K, N., Siewb, N., Lambiec, D., Carnarvonc, R., Ramgattieb, M., \& Knights. (2017). The relationship between circulating concentration of AMH and $\mathrm{LH}$ content in the follicle stimulating hormone (FSH) preparations on follicular growth and ovulatory response to superovulation in water buffaloes. J. Anim. Reprod. Sci. 2 (1) : $1-8$.

Salam, M. H., \& Shibiny, S. E. (2011). A comprehensive review on the composition 
and properties of buffalo milk. Dairy Sci Tehcnol 2(2): 63-99.

Shafakatullah, N., \& Chandra, M. (2014). Screening of raw buffalo's milk from Karnataka for potential probiotic strains. Res J Rec Sci, 3(1) 25-33.

Sharma, R., Sanodiya, B. S., Thakur, G. S., Jaiswal P, Pal S., and Bisen, P. S. (2013). Characterization of lactic acid bacteria from raw milk sample of cow, goat, sheep, camel and buffalo with special elucidation to lactic acid production. Br Microbiol Res $J, 3(2): 743-756$.

Yendraliza., Zesfin, B. P., Udin Z., Jaswandi., \& Arman, C. (2011). Effect of combination of GnRH and PGF2 $\alpha$ for estrus synchronization on onset of estrus and pregnancy rate in different postpartum in swamp buffalo in Kampar regency. $J$. Indonesian Trop. Anim. Agric, 36(1) : 913.

Yendraliza., Zespin, B. P., Udin, Z., \& Jaswandi. (2012). Post-Partum Reproductive Appearance of Buffalo at Various Levels of GnRH and Synchronized with PGF2 $\alpha$. JITV, 17(2): 107-111.

Yendraliza., Handoko, J., Rodiallah, M., \& Arman C. (2017). Characteristics of female oestrus in various synchronization protocols in Kampar District, Riau Province. Pekan baru: Proceedings of the National Seminar on Animal Husbandry Technology and Veteriner: 21(1): 86-91.

Wirdahayati, R. B. (2007). Efforts to Increase the Production of Buffalo Milk for the Conservation of Curd Products in West Sumatra. Bogor: Wartazoa, 17 (4): 178189. 